\title{
IG VII 53, AN EPIGRAPHIC RARA AVIS IN THE CORPUS OF GREEK METRICAL INSCRIPTIONS
}

\author{
Paloma Guijarro Ruano
}

\begin{abstract}
This paper aims to study the inscription published in IG VII 53 from a linguistic point of view. It consists of a prose section that includes an epigram dedicated to the Megarians fallen during the Persian Wars. The inscription was presumably composed in the fifth century BC, but the preserved text was not inscribed before the fourth century AD. After revisiting this text's main scholarship, which has studied this inscription mainly from an archaeological, historical or literary approach, we apply a two-level linguistic analysis based on (a) the comparison of its linguistic data with epigraphical prose and other literary influences, and (b) the metrical constraints that could determine the choice between local and literary forms. As a complement to what current scholarship suggests, this methodological approach will allow us to distinguish to what extent it is possible to trace the original linguistic features of the earliest version of this epigram, as well as whether and how metrics contributed to preserve them.
\end{abstract}

KEYWORDS: Epigram; Megara; dialects; metrics; Metrical inscription.

\section{IG VII 53 at first sight}

Nowadays, the inscription published in IG VII 53 can be found on the northeast wall of Saint Athanasius church in Palaiochori, in the north of Megara. It was discovered by M. Fourmont in the 18th century, and first published by A. Boeckh in 1818, ${ }^{2}$ but current editions of the epigram rely on the corrected version by A. Wilhelm (1899). As we can see from his edition, the text comprises five incomplete elegiac couplets which are preceded and followed by an explanatory prose part:

\footnotetext{
${ }^{1}$ Institut de Sciences et Techniques de l'Antiquité. Université de Bourgogne Franche-Comté. Email: palo.guijarro@gmail.com. This paper is part of the research project FFI2012-35721-Co201, Modos de contacto e interacción dialectal en los textos epigráfico del Griego Antiguo. I thank Alcorac Alonso Déniz and Juan Piquero Rodríguez for their comments and suggestions on an earlier version of this paper. All remaining errors and inconsistencies are, evidently, my own. ${ }^{2}$ First Boeckh's edition appeared in 1818 in the annual archaeological report of the former Universitas Berloninsis, but second edition (more accessible) is usually quoted as Boeckh 1874:125-133.
} 
1

10

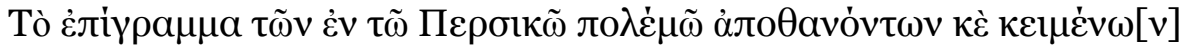

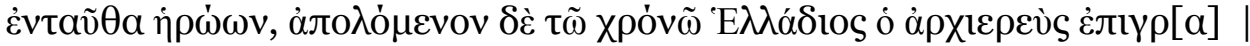

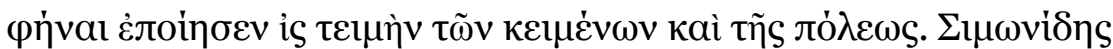

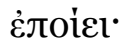

(1)

\begin{abstract}
Helladios the high priest caused the inscription for the heroes who died in the Persian War and lie here, which had been destroyed by time, to be inscribed in honour of the dead and the city. Simonides composed it.

"In striving to promote the day of freedom for Greece and the Megarians we received the lot of death, some beneath Euboea and Pelion, where the shrine called after the holy archer Artemis is situated, others on the height of Mycale, others before Salamis... others on the Boeotian plain, they who dared to pit their strength against men on horseback. Our fellow citizens granted us this privilege, round the centre-stone (omphalos) in the thronging agora of the Nisaeans."

The city has sacrificed a bull right down to our day. ${ }^{3}$
\end{abstract}

The "high-priest" Helladios had an epigram written that was lost with time (1.1-3).4 The verses were dedicated to the Megarians fallen in the Persian Wars, and attributed to Simonides. The recipients of the dedication appear in the first couplet as the subject of the verb $\dot{\varepsilon} \delta \varepsilon \xi \dot{\alpha} \mu \varepsilon \theta \alpha$ "we received", as if they were taking the floor. Here we find the ancient ideal of pro patria mori accomplished by the dead. The three next couplets list the warlike contexts in which the Megarians lost their lives. The final distich turns to the third person

\footnotetext{
3 The version of the Greek text reproduced here is not a standardized one. It presents the original spellings preserved in the monument in order to make more clear the linguistic analysis I carry out in this paper. I reproduce here Molyneux's English translation (1992:199).

4 It seems that Helladios was a pagan priest (according to Petrovic 2007, a priest of Apollo); for further comment and bibliography, see Bravi 2006:66 n.134.
} 
plural, referring to the compatriots who dedicated the monument in the agora. A final prose line mentions the practice of sacrificing a bull.

The entire text constitutes an unusual epigraphical specimen within the epigrammatic tradition. Manuscript collections have preserved many epigrams ascribed to Simonides, however, as far as I know, there is no evidence of an epigram explicitly ascribed to the famous poet of Ceos preserved in a monument. Hence, this rara avis had to overfly many centuries (through different epigraphical and literary contexts) until his final flight alighted her in his current location.

\section{The interpretation of IG VII 53: Context and realia}

\subsection{In the heat of the Persian Wars}

Various elements set the epigram in the context of the Second Persian War (480-479 BC). First, the mention of Euboia with the oronym Pelion (v.3),

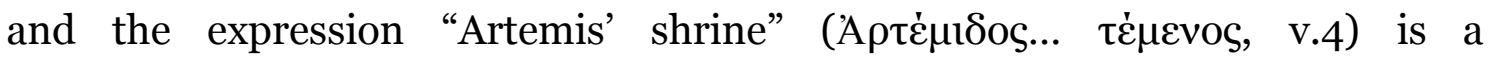
geographical allusion to the Megarian involvement in the battle of Artemisium (480 BC). Indeed, Herodotus (8.11) tells us that the Megarians provided 20 ships for this battle. Second, $\mathrm{M}<v>\kappa a \dot{\lambda} \lambda a \varsigma$ (v. 5) is a clear reference to the battle of Mycale (479 BC), although there is no direct evidence of Megarian intervention in the conflict according to Thucydides' (1.94) or Diodorus Siculus' (11.44.2) account of the struggle. Third, "before Salamis" ( $\dot{\varepsilon} \mu \pi \rho \circ \sigma \theta \varepsilon<v>$ $\Sigma \alpha \lambda \alpha \mu \varepsilon i v o s$, v. 5) refers to the location where the battle of Salamis (480 BC) took place. 5 After an omitted verse (v. 6), which probably began by toì $\delta \dot{\varepsilon}$, the poem continues with a reference to the battle of the Thermopylae ( $480 \mathrm{BC}$ ). ${ }^{6}$ Finally, "in the Boeotian plain" ( $\dot{\varepsilon} v \operatorname{ra\imath } \delta i \omega$ Boı $\omega$ ti $\omega$, v. 7) situates us in the battle of Platea (479 BC), when the war came to an end.

Now that we have established the intended chronological frame within which the epigram should be interpreted, it is time to turn to a discussion on the nature of the epigraphical object and how to interpret the inscription within its archaeological and historical context.

\footnotetext{
5 According to Herodotus (8.45), the Megarians enrolled with 20 ships in Salamis again.

${ }^{6}$ In spite of the fact that Herodotus (7.202) does not mention any Megarian in his casualty lists of the Thermopylae, the most suitable hypothesis is to see a reference to this battle in the omitted verse following the account of the Persian struggles (Wade-Gery 1933:96; Prandi 1990:64 n.42). For Page (1981:215), the allusion to the Thermopylae seems to be a claim of the Megarian intervention in the battle by the own Megarians that erected the monument.
} 


\subsection{A tomb, an omphalos, and an ancient sacrifice of a bull?}

There is some controversy regarding the nature of the tombstone-like monument and its following association to the sacrifice of a bull mentioned in the final sentence (1.15). It seems that, basically, these funerary references must be related to the Megarian practice of honouring the dead soldiers as heroes. All these issues as well as the interpretation of the cultic value of term omphalos (l. 13) are still a matter of debate among scholars.

Much attention has been paid to the nature of the monument, mainly as to whether a grave really existed instead of a cenotaph (an empty tomb). 7 The epigram says that the citizens offered honours to the fallen soldiers in the agora, but in the prose part of the inscription we read "of the heroes who died

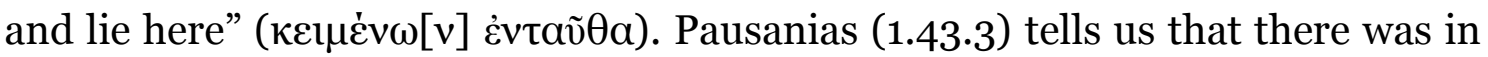

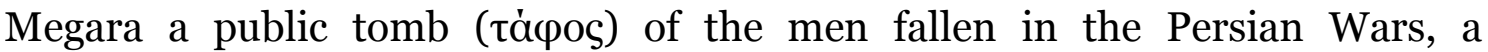
statement that contradicts the tradition of burying the body in the battlefield since, according to Herodotus (9.85.2), the dead soldiers from Megara and Phlious were buried together in Plataea. ${ }^{8}$

These honours provided to the dead soldiers are connected with the final reference to the sacrifice of a bull (1. 15): all this involve that the dead received cult as heroes, at least in the fourth or fifth centuries $\mathrm{AD}$ as from the last remark "right down to our day" ( $\mu \dot{\varepsilon} \chi \rho ı \varsigma \dot{\varepsilon} \varphi ’ \hat{\eta} \mu \tilde{\omega}) .{ }^{9}$ This allusion to the sacrifice also matches with the testimony of Plutarch (c. 46-120 AD) in which he explains that the Plataeans still commemorated the Greeks that lied in the spot in a ceremony where a bull was immolated (Plut. Arist. 21). As Chaniotis asserts, ${ }^{10}$ we are dealing with a revival of an ancient custom rather than a survival.11

Directly associated with this issue is the mention of an omphalos in the Megarian agora. This reference has been understood either as (a) a metaphoric

\footnotetext{
7 For a discussion on an original tomb, see Prandi 1990:64-65. For a discussion on a cenotaph, see Wade-Gery 1933:96-97; Jacoby 1945:172 n.57; Schörner 2007:146-147, 261, for whom the remains of the dead in sea battles could not be recovered.

8 For burial practices, see Clairmont 1983:16-21, 60-73.

9 Boedecker 1997:231-249.

${ }^{10}$ Chaniotis 2005:152.

11 Ekroth 2002:77-78. According to Chaniotis (2005:152), Helladios' words should be understood as a provocation to prevailing Christian laws.
} 
expression meaning "the centre of the city"12, or as (b) an "omphalos", its literal sense, inasmuch as there did exist a similar cultic object in other cities. These items were used as an altar for sacrifices, usually related to the cult of Apollo.13 The interpretation of the term remains open.

Overall, all these questions are related to other attested cultic practices in the agora. For instance, Pausanias (1.43.7-8) reports that the legendary Coroebus was buried in the Megarian agora, and he also mentions the existence of other Megarian heroes' tombs in the bouleuterion, the so-called Shrine of Aesymnium. ${ }^{14}$ Be that as it may, we can conclude that the epigram of $I G$ VII 53 was intended to be written on a grave and that it was meant to leave written record of past history in the centre of the Megarian life. ${ }^{15}$

\subsection{More than eight centuries of history}

We are dealing with different chronological axes depending on the content, the context, the linguistic phenomena, or the epigraphical features attested in the inscription. On the one hand, the semi-cursive script, the mention of the "high-priest" Helladios in the prose introduction, and late linguistic traits $(<\varepsilon>$ for $\langle a l>)$ push forward the inscription's date at least down to the fourth century AD. The connection to Simonides and the internal references in the couplets to the Persian Wars, on the other hand, which must be used only as a terminus post quem, point to the first part of the fifth century BC.

The main difficulty with the epigram's datation lies on how to interpret the passage "Helladios commanded to inscribe the epigram... that was obliterated by time" (1l.2-3). Does it refer to a re-inscription of the epigram

${ }^{12}$ See Bravi 2006:68 n.144, who connects it to a similar expression for the "centre of Athens" in

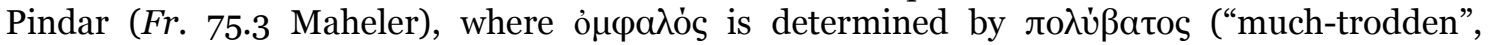

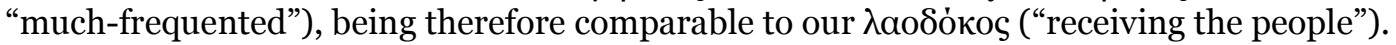

13 Petrovic 2007:199-200 supports the existence of an omphalos in the agora of Megara dedicated to Apollo. His argument is based on a legendary cult of Apollo in the polis (Paus. 1.43.8; Str. 9.394), as well as on the existence of an omphalos in Aegina related to the cult of the fallen in the Persian Wars.

${ }_{14}$ After the end of monarchy, the magistrate Aesymnius went to Delphi to ask the god for the best way to make his region more prosperous. Based on the oracle's answer, the Megarians understood that they should build a council-chamber over the tombs of their heroes in order to make better decisions. The name of Aesymnius lies in the local council-chamber.

${ }_{15}$ See in this regard Clairmont 1983, especially page 101. Petrovic (2007:197-198), following Pausanias' testimony, argues for the designation of the dead as heroes in the prose part of the inscription, as well as for the existence of a heroon in the agora. For a possible change of location of the bodies in 460 BC, see Prandi 1990:64 n.44, with bibliography. 
because the original was illegible, or does it simply mean "inscribed" from a previous version whose original belonged to an epigrammatic anthology? ${ }^{16}$ In Petrovic's opinion, the text was copied from an omphalos which was damaged along with the destructions underwent by Megara before and during Helladios' time. ${ }^{17}$ There is no definitive answer to this issue. The debate only suggests that for readers in the fourth $\mathrm{AD}$ it existed a chronological gap between the two versions.

\section{The extant version of the text}

In addition to epigraphical collections and numerous studies, the epigram is also integrated in Simonides' anthologies. ${ }^{18}$ In this paper, we follow Wilhelm's edition (1899) with later corrections made by Wade-Gery (1933). For a better comprehension of the text, I reproduce below Wilhelm's (1899:238) facsimile:

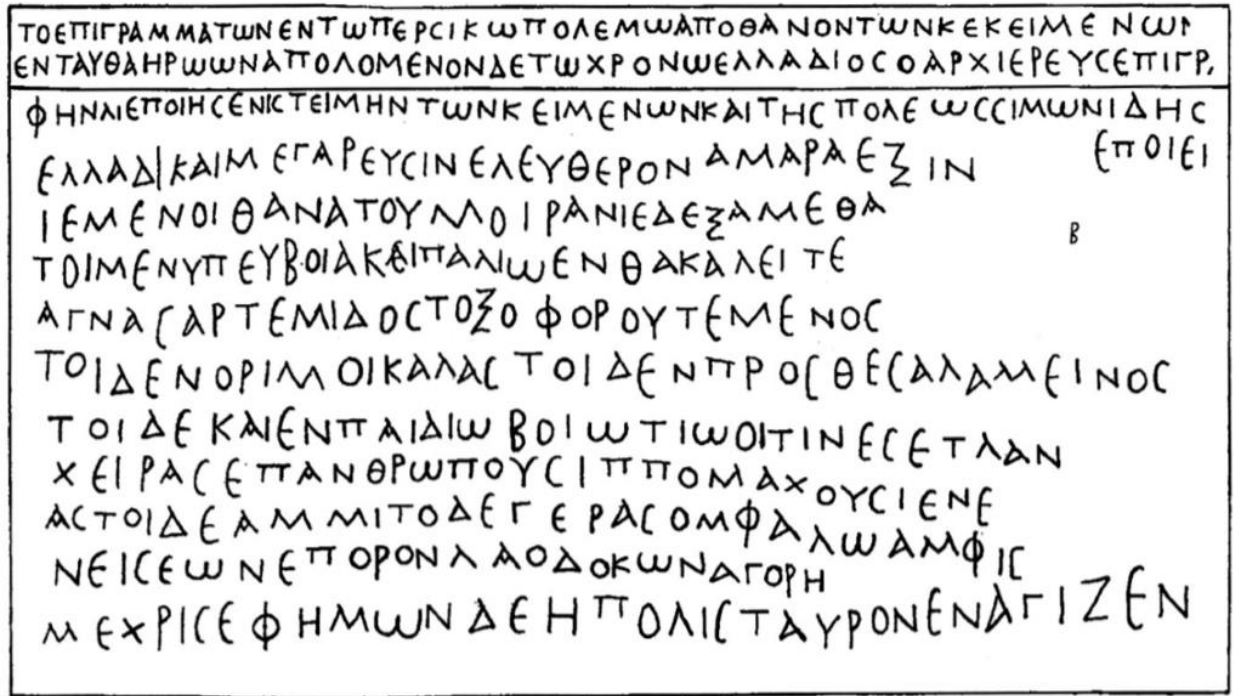

${ }^{16}$ For epigrammatic collections, see Argentieri 2007.

${ }^{17}$ See Petrovic 2007 (especially page 206) with bibliography.

18 The most relevant editions are the following: CIG 1051; Kaibel $1878 n^{\circ} 461$; Wilhelm 1899; Hiller von Gaertringen $1926 \mathrm{n}^{0} 30$; Wade-Gery 1933:95-97; Friedländer 1938:120; Tod 1951 n ${ }^{20}$; SEG 13.312, GVI 9; Pfohl 1966:75, 209 n.82; Vries 1967 n.12; Podlecki 1973:25; Page 1975, 1981; Chaniotis 1988, D 57; Molyneux 1992:199-200; Bravi 2006:65-68; Petrovic 2007:194208; Schörner 2007:261-262). For literary editions under Simonides' authorship, see Sim. Fr. 107 Bergk and Fr. 96 Diehl (Diehl's is based on editions previous to Wilhlem's corrections). For secondary studies, see bibliography in Schörner 2007:262. 


\subsection{Misspellings and errors}

The inscribed text presents some important issues regarding editing, dating, and interpretation on account of its irregular spellings and errors. First, the letters' rendering is not homogeneous (see for instance, the different shaping for $\langle\mathrm{A}>$ ), and the lines' layout is very uneven. Second, an entire pentameter in v.6, and a word in v.9 are omitted due to a careless copy. Third, some letters are missing as well ( $\dot{\varepsilon} \mu \pi \rho \circ \theta \varepsilon<v>$ v.5), and others are incorrectly added ( $\{\mathrm{l}\}$ v. 3). For a better comprehension of the text, it is necessary to accept

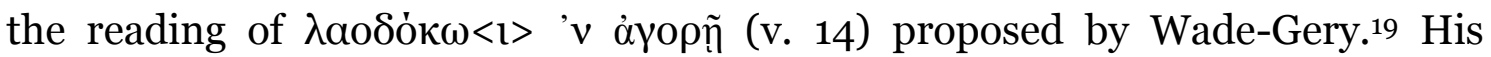
interpretation as a dative form in accordance with agora is the most suitable way to explain the presence of this adjective ('receiving people') in the inscription (for the prodelision of $\dot{\varepsilon} v$ see §4.1.1).

The text presents graphic misspellings owed to the late pronunciation both in the prose and in the verse sections (\$4.1). Thus, we find $\langle\mathrm{l}\rangle$ for $\langle\varepsilon \mathrm{l}\rangle$ in

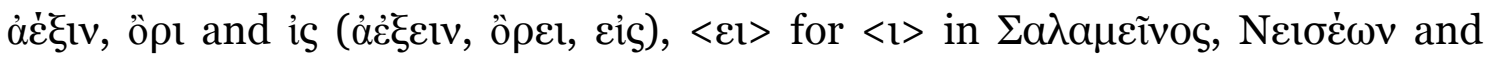

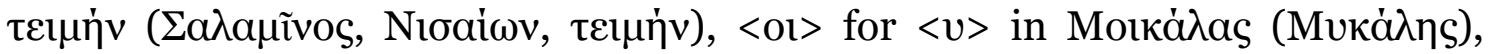

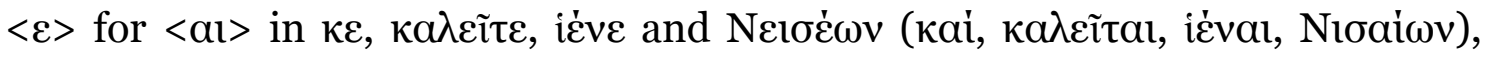
and $\langle a l>$ for $\langle\varepsilon>$ in $\pi \alpha ı \delta i \omega(\pi \varepsilon \delta i \omega)$. The unexpected imperfect $\dot{\varepsilon} v a \gamma i \zeta \varepsilon v$ instead of $\dot{\varepsilon} v \eta \gamma i \zeta \varepsilon v$ can be understood as a later form without its augment (like in Ptolemaic papyri) or, more simply, as a mistake according to the aforementioned graphic inconsistencies. ${ }^{20}$

\subsection{The original version... literary or epigraphical?}

Regarding the preserved epigram, there is no agreement among scholars about (a) the existence of an earlier version, either epigraphic or in other form, (b) the original number of verses, and (c) the ascription to Simonides. Some authors believe that the text was a copy from a book with an anthology of epigrams, because of its spellings, misspellings, and the nongeneralised practice of marking the authorship in archaic and classical

\footnotetext{
19 Wade-Gery 1933:95.

${ }^{20}$ For Page (1981:213 n.2), $\dot{\varepsilon} v a \gamma i \zeta \varepsilon v$ is less used than the present $\dot{\varepsilon} v a \gamma i \zeta \varepsilon$. The imperfect is a better match, especially if Chaniotis' hypothesis (2005:152) is correct, see §2.2. For other

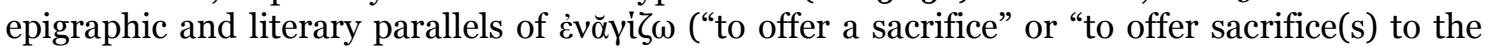
dead") applied to a context of honouring of fallen soldiers or heroes, see DGE s.v. $\dot{\varepsilon} v \alpha \gamma i \zeta \omega 1$.
} 
periods. ${ }^{21}$ Other scholars, to the contrary, see an original dating from the fifth century $\mathrm{BC}$, which was ascribed to the poet. ${ }^{22}$ As it stands, the poem is disproportionately long in comparison with other Persian War epigrams, and pre-Hellenistic metrical inscriptions. ${ }^{23}$ Consequently, it has been suggested that a first original distich was later extended, a common phenomenon in late anthologies. ${ }^{24} \mathrm{~A}$ third line of interpretation argues that all the couplets belonged to the first version, given the existence of other inscriptions dating from this period with more than two verses. ${ }^{25}$ However, most of the long cognates are found in more recent metrical inscriptions and in epigrams transmitted by medieval sources (sometimes also ascribed to Simonides). ${ }^{26}$ According to Petrovic, ${ }^{27}$ there are three main reasons for supporting the idea that the last couplet was a later addition from a literary source: (a) the reference to the settlement of the dedication, useful for a reader of epigrams transmitted in collections or books where the original epigraphic context was lost, (b) the ethnic Nıoaĩol, unusual before the fifth and fourth centuries BC for distinguishing Megara from Megara Hyblaea, ${ }^{28}$ and (c) the epigram's attribution to Simonides, since in epigraphic poetry epigrams are not signed before the fourth century BC. 29

\footnotetext{
${ }^{21}$ See Wilhelm 1899 and Wade-Gery 1933:96. The latter does not date the original text's composition.

${ }^{22}$ Page 1981:213-215.

${ }^{23}$ For literary epigrams attributed to Sim., see Page 1981:nn.XI-XIII, XV, XXIV or XXXIV.

24 Wilhelm 1899; Friedländer 1983; Pfohl 1966; Petrovic 2007. The same applies to two epigrams dedicated to the Corinthians fallen in the Persian Wars: CEG 131 (Corinth, post 480 BC), which was later appended to its literary version; and Page 1981:n.XII (97 Bergk), whose length depends on the literary version that one quotes from.

25 Wade-Gery 1933; Podlecky 1973; Page 1981; Molyneux 1992. Longer archaic metrical inscriptions are CEG 143 (Kerkyra, c.625-60o?) and CEG 108 (Eretria, c.450 BC?); see further analysis in Chaniotis 1988:236ss. Megara's metrical inscriptions from the classical period do not offer further information (cf. $C E G 133,5^{\text {th }}$; $C E G$ 134, c. 500?; and in the $4^{\text {th }} C E G 654$ and $C E G$ 655 ). There is only one exception, $C E G 134$, which presents more than one couplet.

${ }^{26}$ See the three-distich epigram $I G$ VII 52 ( $2^{\text {th }} \mathrm{AD}$ ), probably later re-inscribed from a literary copy as well (Petrovic 2007: 204), or the twelve-line epigram of AP 13.19 by Simonides.

27 Petrovic 2007:194-208.

${ }^{28}$ See Petrovic 2007:204 n.45. According to Bravi (2006:68 n.144), the ethnic could be referring to Megara's second harbour (also called Nisaea) in order to emphasize the naval force provided by the Megarians during the war, but the relationship between the agora and the omphalos remains to be explained. An allusion to Megara as "the city of Nisos" can be clearly seen in new

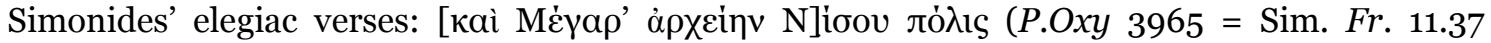
West).

${ }^{29}$ In support of this hypothesis, Petrovic states that we should expect $\tau \varepsilon \dot{x} x \omega$ instead of $\pi$ oic $\omega$ reserved for artisans or monument-builders in the signing of metrical inscriptions. The first signatures in epigraphic poetry are that of Ion of Samos (CEG 819, Delphi < Laconia, 350-300 BC?), Symmachos of Pelene (CEG 888, Lydia, $4^{\text {th }}$ BC; $C E G$ 889, Lydia, $4^{\text {th }}$ BC), and there is an semi-obliterated one in $C E G 700$ (Cnidus, $4^{\text {th }} \mathrm{BC}$ ). Here $\tau \varepsilon \dot{\chi} \chi \omega$ stands alone or with or $\dot{\varepsilon} \lambda \varepsilon \gamma \varepsilon \tilde{\alpha} \alpha$. It
} 
The false ascription of epigrams, especially the ones about the Persian Wars to Simonides, was a common practice in the literary tradition, and many studies try to deal with their authenticity. ${ }^{30}$ This custom is based on the common practice of composing epigrams for the dead soldiers. It developed in the fifth century $\mathrm{BC}$ when the polis offered funeral honours in public spaces to its benefactors, but mostly spread out from the Hellenistic period onwards. This piece of evidence also matches with the later trend of assigning epigrams to famous authors, as is the case here. ${ }^{31}$ Thus, epigrammatic anthologies and collections of (pseudo-)Simonidean poems did exist. ${ }^{22}$ The connection between the poet and Megara can be traced by a scholion to Theocritus' Idyll. 12 (27 Ss.), according to which the poet praises the Megarian sailors that participated in the Persian conflict.33 However, concerning the authorship of the verses in IG VII 53 proper, Page dismisses altogether the ascription to Simonides, and considers that a good candidate for the epigram would be instead the Megarian poet Phliadas, although his chronology is not sure and there is no evidence to demonstrate it. 34 Bravi sees the influence of a local poetic oral tradition and refuses a preliminary literary version of the text, but his hypothesis has no grounds. 35 By contrast, Wade-Gery's interpretation seems quite plausible: "the local antiquaries of Megara (we may suppose) knew and preserved those poems in the 'Simonides' collection which referred to their town". ${ }^{6}$ To sum up, there are no decisive arguments to accept the poet from Ceos as the composer of the epigram. Yet, there are no reasons to deny a later ascription as well, inasmuch

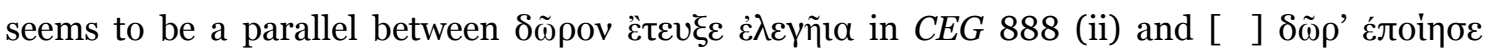
$\dot{\varepsilon} \lambda[\varepsilon \gamma \tilde{\eta} \mathrm{I}(\alpha)]$ in $C E G 889$ (ii), both placed in the first part of the verse (an hexameter or pentameter) and coming from the sanctuary of Leto in Xanthus. See in this regard Guijarro Ruano 2016:42-43, 187-188.

30 Boas 1905; Page 1981; Podlecki 1973; Molyneux 1992 (especially, pages 147-210); Chaniotis 1988; Petrovic 2007. See also Pausanias 9.2.5.

${ }^{31}$ There are more parallels of funeral honours offered in an agora to a group of citizens who lost their lives in the name of their homeland, for instance, the Oresthasians died in Phigalea (Paus. 8.41.1) or the fallen in Plataea (Thuc. 3.58; Plut. Arist. 21). Also individual citizens were commemorated, like Philippe of Crotone, dead for the Segestan people (Hdt. 5.47); Maion and Aplheios, fallen for Sparta; or Talthybios whose tomb was in the agora of Aegium in Achaea (Paus. 12.7). For the religious function and heroic cult of the agora, see Martin 1951:164-201 (especially 194-201).

${ }^{2}$ See Argentieri 2007 and Sider 2007 respectively.

33 See Kaibel 1873:455; Boas 1905:79 n.3. For a recent discussion, Petrovic 2007:207.

34 Page 1981:214.

35 Bravi 2006:67.

${ }^{36}$ Wade-Gery 1933:96. 
as other epigrams related to the Persian Wars had authorship attributed in later periods.

\section{A linguistic overflying over IG VII 53}

Metrical inscriptions, as metrical and epigraphical texts, are expected to be influenced by poetic or literary languages as well as by local dialects. In the following sections, the linguistic data of the text are re-examined in a two-fold analysis, which consists of (4.1) a comparison of IG VII 53 with both epigraphic prose and literary poetic tradition(s), and (4.2) a classification of the epigram's traits according to metrical constraints. Through this analysis we could then differentiate and date a two-level linguistic phenomenon: the ones corresponding to the fourth century $\mathrm{AD}$ onwards (when the epigram was copied), and the original linguistic traits hidden behind the more recent spellings. This approach will provide us new arguments for accepting or dismissing the authenticity of the last couplets of the poem.

\subsection{Analysis of linguistic features}

Once the text has been deprived of the more recent linguistic features characteristic of a later pronunciation of Greek (already mentioned in §3.1), we observe that linguistic inconsistences are here at ease according to the general neglected style of the copied text. For instance, $\kappa a i$ is written $\kappa \dot{\varepsilon}$ in the prose introduction (1.1) and in contrast preserved in the verse part as kai (vv. 1, 7) but corrected by the scribe $\kappa \dot{\varepsilon}$ for kai (v.3). This careless version of the texts points to the modest background of the copyist.

\subsubsection{Doric and/or local influence}

At first sight, there are no specific epichoric traits in the inscription. Had they existed, they most certainly would have been hidden, that is, they would not have been found in the (recent) version of the text. Since IG VII 53 comes from Megara, and Megara is in the West, it is important to point out that sometimes there is no neat difference between local dialects and what is called "Doric" in West areas. In this way, we can understand both Doric dialects and Doric poetic tradition in a broad sense. More specifically, we can understand Doric poetic language as opposed to Ionic poetic language with regard to the 
composition of epigrams from the Hellenistic period onwards. 37 This is why it is not possible to differentiate whether the preservation of $\bar{\alpha}$ in $\tilde{\alpha} \mu \alpha \rho$ (v.1), Eủßoi $\alpha$

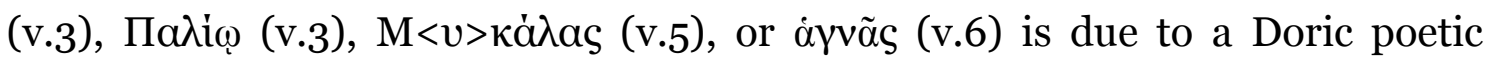
tradition or to a local dialect. In fact, $\tilde{\alpha} \mu \alpha \rho$ is accompanied by $\dot{\varepsilon} \lambda \varepsilon \dot{v} \theta \varepsilon \rho o v$ in a well-known poetic expression (\$4.1.3.), and $\dot{\alpha} \gamma v \tilde{\alpha} s$ qualifies the non-Doric form

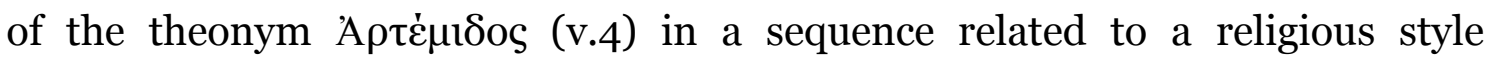
differentiated from ordinary speech. The oronym $\Pi \alpha \lambda i \omega$ (v.3) is the equivalent

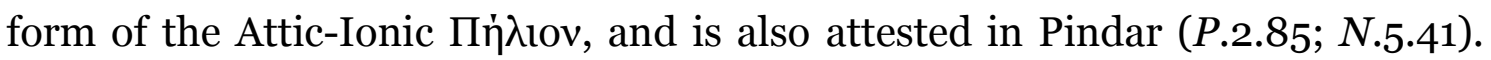
With these connections in mind, Page argues that the epigram's composer presumably was a Megarian, and that חá $\lambda$ ıov was a "token of the high antiquity of the composition". ${ }^{38}$ However, these features could also derive from an intended archaic style, as if it was a "Dorization" of a more recent Ionic form of $\Pi \dot{\eta} \lambda$ ıov. Hence, the term $\mathrm{M}<v>\kappa \alpha \dot{\lambda} \alpha \varsigma$ ("Mycale") could well be an Ionic form

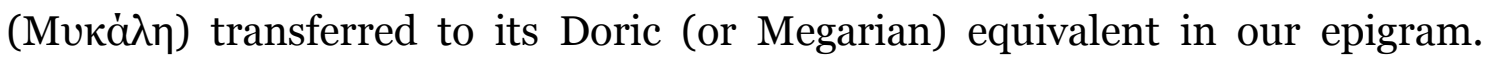
Furthermore, the preservation of $\bar{\alpha}$ in Ev̉ßoi $\alpha$ (v. 3) could be explained as (a) the local form of the toponym in the island of Euboea, 39 (b) the Doric (or Megarian) form of the name, or even (c) an Attic form, as many other Attic forms were preserved in Koine. In any case, it is noteworthy that expected Doric $\bar{\alpha}$ forms

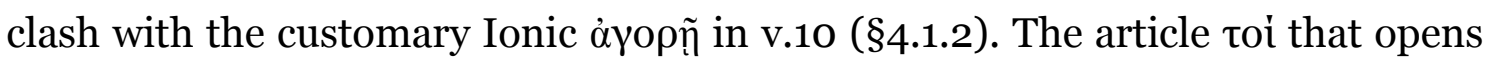
the second, third, and fourth hexameters could also be due to a Doric or epichoric influence. Concerning $\tilde{\varepsilon} v \pi \rho 0 \sigma \theta \varepsilon<v>$ (v.5), the absence of a final $-v$ can be justified as an interference with the local dialect but, most probably, it is a case of mere misspelling. $4^{0}$

No more specific local features can be found in the epigram: there is no trace of word-initial f- in àotoi, ${ }^{41}$ and $\chi \varepsilon \tilde{i} \rho \alpha \varsigma$ presents the same /e:/ as in Attic-

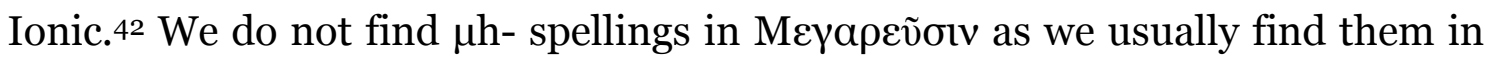

\footnotetext{
37 In this regard, see Guijarro Ruano 2016:59-60, 555-557.

${ }^{38}$ Page 1981:215.

39 Del Barrio Vega 1987:111, 122-123.

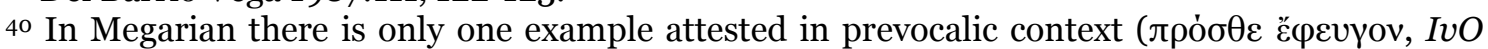
22, Olympia < Megara, 6 BC). See Bechtel 1923180-181 §23.

${ }^{41}$ In Corinthian and Megarian * $w$ - > f- appears until the fifth century BC (also ${ }^{*} s w->f^{-} / \mathrm{fh}-$ ), but there are no specific examples of * wastu- in documents of the area and the earlier cases of loss in this position are dated between the sixth and fifth centuries BC. See Bechtel 1923:169-170 $\S 3$.

${ }_{42}$ The expected epichoric form is $\left\langle\right.$ XEPA $\Sigma>$. For $\chi \varepsilon\left\llcorner\rho^{\circ}\left(<{ }^{*} g\right.\right.$ 'hes- $\left.r\right)$, see Bechtel 1923:177-178 $\S 15$.
} 
the fifth century BC. 43 Anyhow, the use of their local equivalents would not have affected the metrical structure of the verse. Other forms such as the genitives

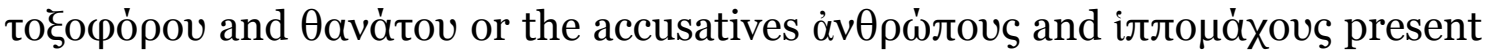
the expected vocalic result /o:/ $(=<\mathrm{ov}>)$ in Megarian as well as in Attic-Ionic dialects. Finally, we cannot be sure about the interpretation and correction of

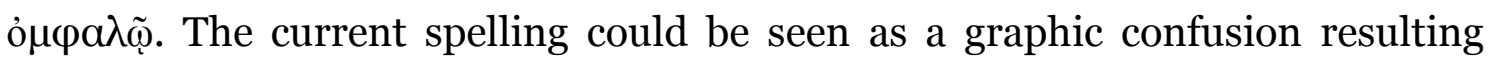
from an epichoric spelling $<\mathrm{O}>$ which, in a later copy from an epigraphical model, was re-interpreted as - $\omega$ and not as -ov.44 Such an assumption is a way of explaining $\dot{\alpha} \mu \varphi i \varsigma$ + dative instead of the genitive with the sense of "far from" (v.9). In Homer, however, we do find parallels of $\dot{\alpha} \mu \varphi \dot{i}+$ dative with the same meaning of "around". 45

\subsubsection{Non-Doric features}

The epigram presents some linguistic features alien to the epichoric dialect. The most striking example is the Lesbian pronoun ö $\mu \mu \mathrm{r}$ (v.9), which contrasts with the expected local form $\dot{\alpha} \mu$ ĩv (although $\dot{\eta} \mu \tilde{v} v$ appears in the final prose line). ${ }^{6}$ The influence of Aeolic-Lesbian poetic features in pre-Hellenistic epigraphic poetry is less evident than the epic or elegiac one. Aeolic elements are restricted to features particularly used for metrical convenience or because of its prestige. 47 This could be the case here, but (a) $\ddot{\mu \mu \mu(v) ~ d o e s ~ n o t ~ a p p e a r ~ i n ~}$ inscriptional epigrams prior to the fourth century $\mathrm{BC}, 4^{8}$ and (b) we cannot dismiss the possibility of an original Doric form <AMI> reinterpreted as $\ddot{\alpha} \mu \mu$ throughout the transmission of the text. In any case, the introduction of Aeolic features in later epigrams is well attested.

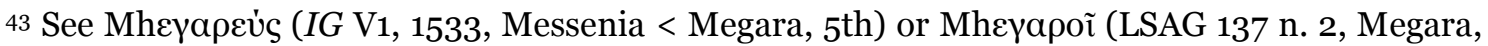
c.500). For instances in metrical inscriptions, see Guijarro Ruano 2016:316.

44 Bravi 2006:67 n.137.

45 See DGE s.v. $\dot{\alpha} \mu \varphi$ ic. This argument is more developed in Petrovic 2007:202.

${ }^{46}$ For the first plural person in Megarian, see ac. $\dot{\alpha} \mu \dot{\varepsilon}$ (IosPE I² 352, Chersonesus, $107 \mathrm{BC}$ ), and gen. $\dot{\alpha} \mu \tilde{\omega} v$ (IG VII 21, Megara c. 200 BC). In Aristophanic comedy we find $\dot{\alpha} \mu \dot{\varepsilon}$ (Ar. Ach. 759) and $\dot{\alpha} \mu \tilde{i} v($ Ach. 821).

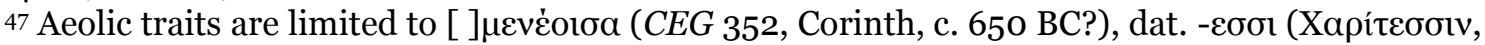

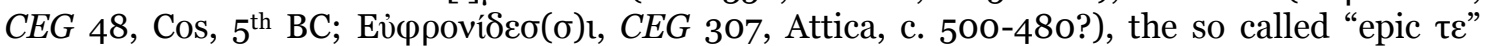
( $C E G$ 51, Athens, c. 510 BC?; $C E G$ 268, Athens, c. 480-470?; $C E G$ 124, Thessaly, c. 450-425?), and it has been alleged $<$ EMI $>(=\dot{\varepsilon} \mu(\mu) \hat{i})$ in $C E G 118$ (Thessaly, a. 500-475?). See Guijarro Ruano 2016:252-255.

${ }^{48}$ Later, $\grave{\alpha} \mu \mu \mathrm{u}$ or $\grave{\alpha} \mu \mu \mathrm{v}$ is well attested in metrical inscriptions. See, for instance, $I G \mathrm{II}^{2} 8494$, Attica, $3^{\text {rd }}$ BC; SEG 28.737, Gortyn, $170-164$ BC or IGUR III 1316.9 , Rome, $3^{\text {rd }} 4^{\text {th }} \mathrm{AD}$ ). In $I G \mathrm{II}^{2}$

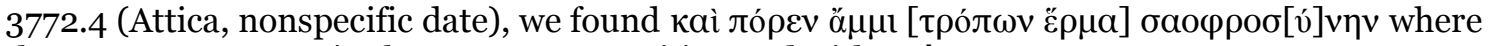
the pronoun appears in the same verse position and with * $\pi$ ó $\omega$.
} 
There are other non-Doric influences in the text, such as the Ionic $\dot{\alpha} \gamma o \rho \tilde{n}$

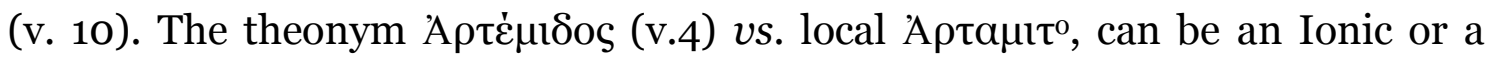
Koine feature, because A $A \tau \varepsilon \mu 1 \delta^{\circ}$ became the commonest form of the word from

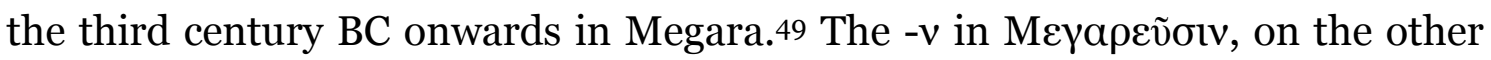
hand, is not a dialectal fact. It should be understood as a poetic technique used to easily add a light word-final syllable before a vowel. Apart from the AtticIonic dialects, the treatment of this $-v$ in ephelkystikon is not very systematic in other epichoric dialects, but its exploitation as metrical and poetic resource is well attested from the earliest inscriptions in verse. ${ }^{\circ}$ In the same line of

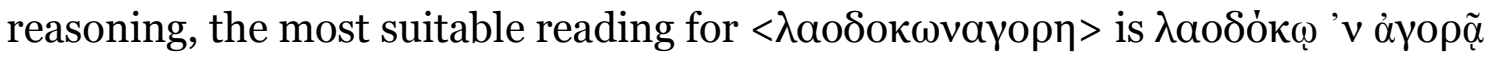
(§3.1). Given that the final iota of the dative singular was not pronounced in this period, we could interpret this sequence as a probable case of prodelision. Yet, this phenomenon is not common within metrical inscriptions prior to c.300 BC. ${ }^{11}$ Furthermore, the use of $\lambda$ aodókos as an adjective and not as a personal name raises some chronological problems. If this use derives directly from the

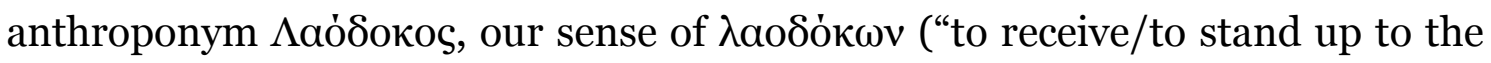
people") is difficult to explain according to the genitive $\mathrm{N}\left\langle\mathrm{l}>\sigma<\alpha \mathrm{i}>\omega v .5^{2}\right.$

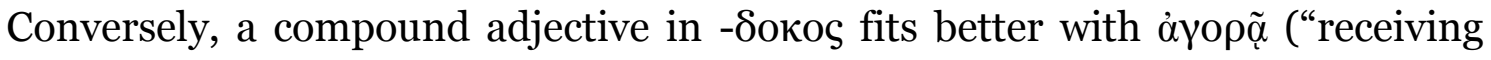
people", "crowded", "thronging"). If this hypothesis is correct, it supports a late date for the last distich, since these adjectives in -бокоร are more recent -unless there is a reason for calling the Megarians "receivers of people" that remains unnoticed by us.

Finally, there could exist an enjambment between the final two verses of

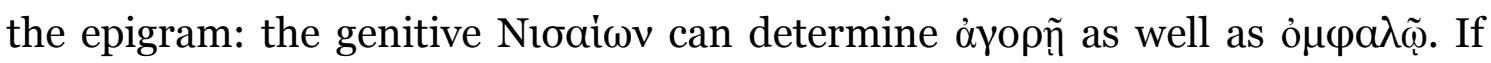
this is the case, we would have a more complex syntax device with no parallels neither in any other part of the epigram nor in any other instance of pre-

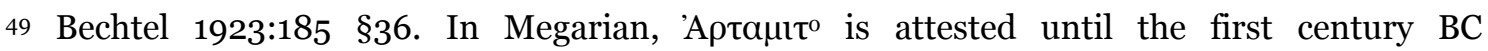

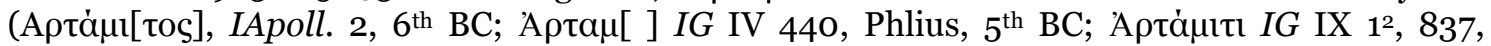

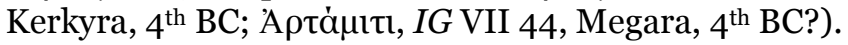

${ }^{50}$ Guijarro Ruano 2016:403-411.

${ }^{51}$ There are no clear examples of prodelision in metrical inscriptions. Instead, it is more likely to

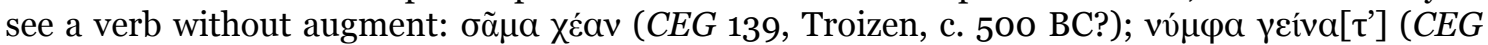
824, Delphi < Arcadia, c. 369 BC). In $\varphi \theta \mu \mu \varepsilon ́ v \eta ~ ' \chi \omega ~(C E G ~ 89$, Athens, c. 410 BC), crasis should not be excluded. For this phenomenon in pre-Hellenistic metrical inscriptions, see Guijarro

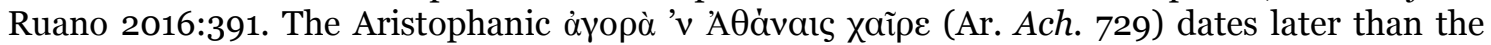
assumed context for our epigram, and the example loses importance when compared to epigraphical data.

$5^{2} \Lambda$ aóookos, already attested in Mycenean ra-wa-do-ko (Py Ea 802), can have the active or passive meaning as $\delta \dot{\varepsilon} \chi o \mu a l$. In this regard, see Kamptz 1982:73.
} 


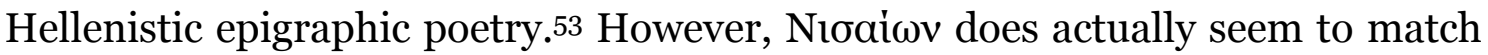
better with $\dot{\alpha} \gamma \rho \rho \tilde{\eta}$.

\subsubsection{Poetic expressions}

The epigram is full of expressions that point to an inherited poetic language. A particularly remarkable expression is the Homeric $\dot{\varepsilon} \lambda \varepsilon \dot{v} \theta \varepsilon \rho o v \tilde{\alpha} \mu \alpha \rho$ ("the day of freedom") in which $\tilde{\alpha} \mu \alpha \rho$ is used instead of $\dot{\eta} \mu \dot{\varepsilon} \rho \alpha .54$ This expression is followed by the verb $\dot{\alpha} \dot{\varepsilon} \xi<\varepsilon>\mathrm{v} v$, the poetic equivalent to $\alpha \tilde{v} \xi \omega$ (in a zero grade

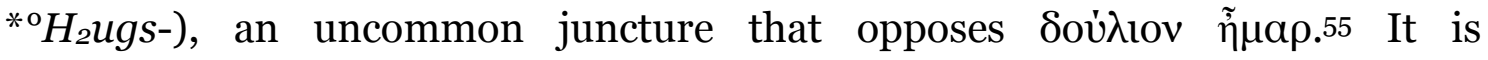
noteworthy that both expressions are epigraphically attested.56 There are other

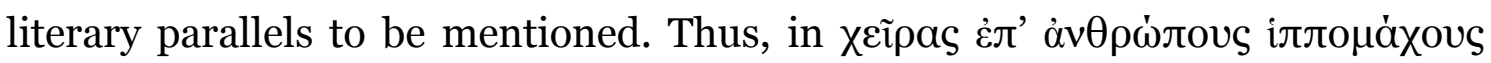
ićval (v.10) we can observe, first, the influence of the Homeric construction $\dot{\varepsilon} \varphi \operatorname{in} \mu \mathrm{r}+\chi \varepsilon \tilde{\imath} \mathrm{\rho} a \varsigma$ + dative ("lay hands on somebody") 57 and, second, an allusion

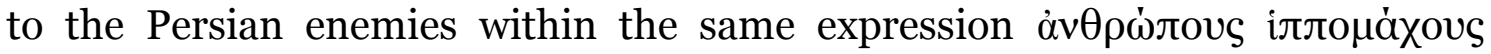
quoted in another epigram attributed to Simonides (AP 6.2).

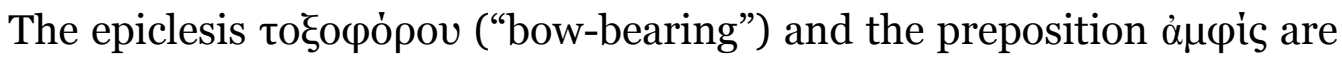
poetic words as well. The former is a recurrent epithet for Apollo and Artemis 58

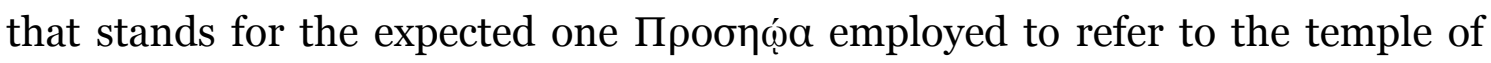
Artemis located in the cape of Artemisium.59 The latter also points to a poetic usage: instead of the more usual $\dot{\alpha} \mu \varphi \dot{i}$, all the epigraphic occurrences of $\dot{\alpha} \mu \varphi \operatorname{is}$ appear exclusively in metrical contexts. ${ }^{60}$ Another noticeable expression is

53 See Wilhelm 1899:241, and more recently Petrovic 2007: 202.

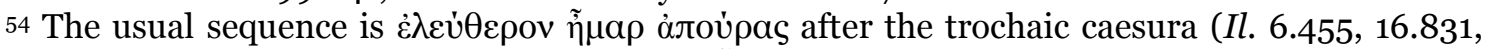

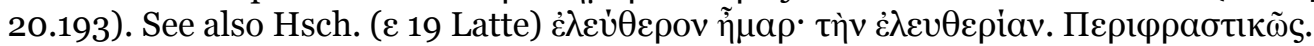

55 Epic expressions like $\dot{\alpha} \dot{\varepsilon} \xi \omega+$ i $\varepsilon \rho o ̀ v ~ \tilde{\eta} \mu \alpha \rho$ in the Epos (Il. 8.66, 11.84; Od. 9.56) may be the basis for this uncommon association Petrovic 2007:200.

${ }^{56}$ See the metric in CEG 2 (Athens, post 479 BC), and more recently in I. Cret. I, 147, no.48

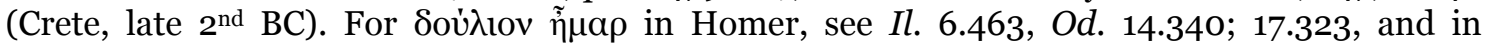
inscriptions $I G \mathrm{I}^{2} 763$ (Attica, c. $479 \mathrm{BC}$ ?), $I G \mathrm{II}^{2} 5^{227^{\mathrm{a}}}$ (Attica, 287/6 BC). The phrase is also

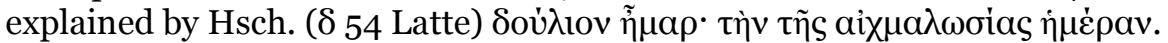

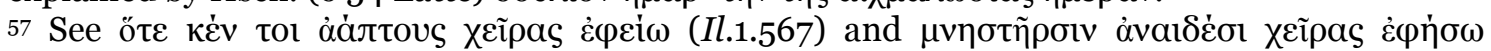
(Od.20.39). The construction în $\mu \mathrm{l}+\dot{\varepsilon} \pi \mathrm{i}$ (+ acc.) is well attested. See $L S J$ s.v. غ̇ंi.

${ }_{58}$ Epithet already attested in Homer (Il. 21.483). For metric inscriptions, see IG V1, 960 (Laconia, undated) and IK Sestos 11 (Kallipolis, undated). The latter is dedicated to Apollo.

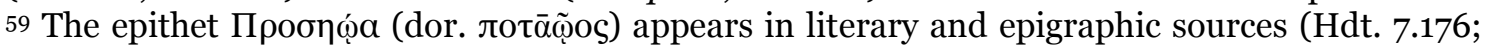
Plut. Them. 8, and $I G$ XII, $91189.4-5$, Euboia late $2^{\text {nd }} \mathrm{BC}$ ). The cultic epithet "towards the East" indicates the position of the temple in the cape from the point of view of the sailor who enters into the gulf.

6o IGUR III 1303f (Rome, late 1st c. AD), SEG 23.121 (Marathon, 160/161 AD), SEG 25.806 (Scythia, $1^{\text {st }}-2^{\text {nd }} \mathrm{AD}$ ), IG XII, 5304 (Paros, non-specific date), IG XII, 5590 (Ceos, non-specific date), IGUR III 1224 (Rome, undated), and probably SEG 25.295 (Markopoulo, c. mid-4 ${ }^{\text {th }}$ c. BC) and $S E G$ 17.502 (Yeniköy [Ionia], undated). 


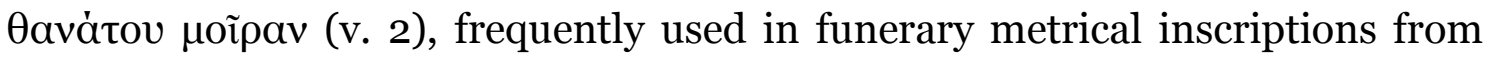
the sixth century $\mathrm{BC}$ onwards. It was especially common in Attica, being always

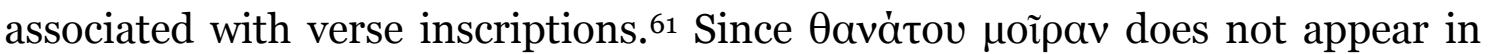
literary texts in earlier times, it can be considered as a typical formula in epigraphical poetry.

\subsection{The metrical constraint}

Once classified the linguistic characteristics of the text, we can now turn to the analysis of how metrics determines the choice of a given trait, and to what extent it helps to preserve original dialectal forms. Leaving aside the prose part and Koine features of the epigram, the evidence seems to suggest that the use of literary and/or artificial terms constituted a deliberated attempt and not a fortuitous linguistic fact. The election was conditioned by their more or less suitability to fit into the metrical pattern.

\subsubsection{Non-metrically equivalent pairs}

In the sense of the internal metrical structure of the words, not only the

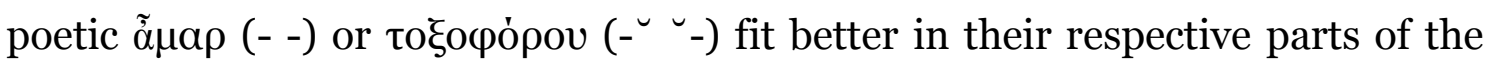

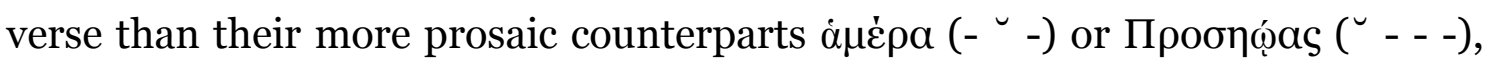

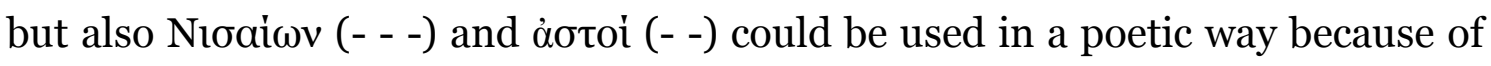

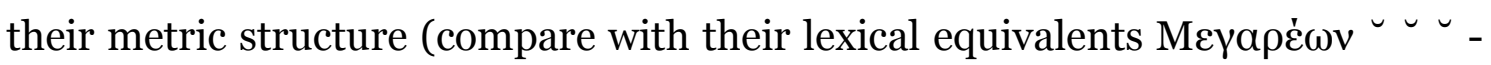

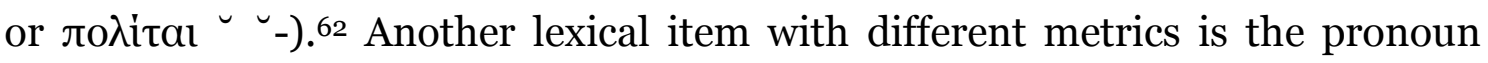
$\ddot{\alpha} \mu \mu \mathrm{u}\left(-{ }^{\smile}\right)$. Such a difference can be due to an Aeolic poetic tradition, but in the Homeric vulgata the pair $\ddot{\alpha} \mu \nu$ - $\ddot{\mu} \mu \mathrm{v}$ is also employed according to metrical constraints. This is why the epic tradition may have influenced other poets, as well as later epigrammatic poetry. ${ }^{63}$ The lack of $-v$ ephelkystikon is imperative

\footnotetext{
${ }^{61}$ CEG 67 (Attica, c. 500 BC?), CEG 77 (Eretria < Attica, c. 500-475?), CEG 158 (Thasos, c. 525500?), CEG 561 (Attica, c. 350 BC?).

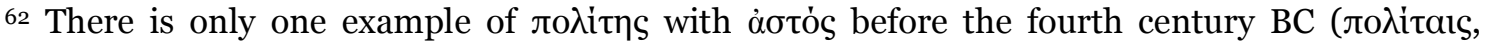

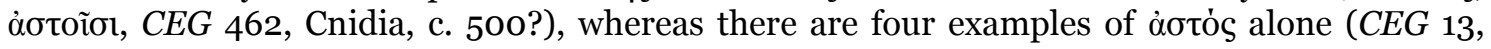
Attica, c. 575-550?; CEG 112, Thisbe, c. 500 BC?; CEG 123, Thessaly, c. 450-425?; CEG 172, Apollonia Pontica, c. 490; and $C E G$ 462). Two of them are in the first position of the hexameter/pentameter $(C E G 112,123)$. In the fourth century, there are three examples of àotós (CEG 483, Attica, $C E G$ 692, Rhodes; $C E G$ 705, Cos), and only one of them is in the incipit of the verse (CEG 483).

63 The same applies to $\grave{\nu} \mu \mu \mathrm{l}-v \mu \mu \mathrm{v}$, see Chantraine 1958:§127. In literary epigrams, $\grave{\alpha} \mu \mu \mathrm{t}(v)$ appears in the same position as in $I G$ VII 53 ( $A P$ 1.22, 1.27, 1. 95, 7.42, 7.577 and 15.40), but also in the middle of hexameters and pentameters $(A P 5.254,7.198,7.467,7.540,7.581,9.142$,
} 
for the correct prosody of the verse: $\dot{\alpha} \mu$ iv is more commonly employed in Doric, but its use would have created an irregular second longum (- -). As a result, the pronoun $\ddot{\alpha} \mu \mathrm{\mu}$ is justified in prosodic terms, and its presence in the epigram is significant for the hypothesis of a later addition of the last distich, due to the lack of other instances of this Aeolic dative in early epigrams. Therefore, the,

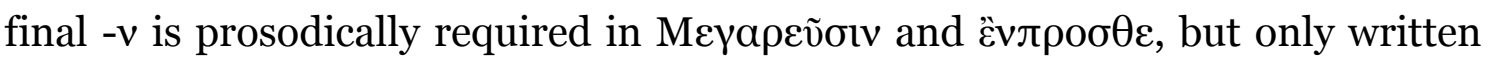
in the first case.

\subsubsection{Metrically equivalent pairs}

The intentional poetic character of the text is lexically reinforced not only by the use of $\dot{\alpha} \dot{\varepsilon} \xi<\varepsilon>\mathrm{lv}$, whose metrical scheme ( ${ }^{-}-$) is identical to the

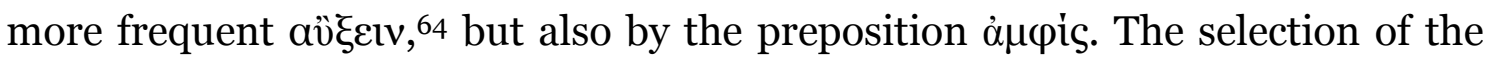
form with the mobile $-\varsigma$ does not affect the meter. On the other hand, the final $-v$ is not a dialectal fact, but a tool that is used depending on metrical requirements. There are three different results in our text: (a) a metrically

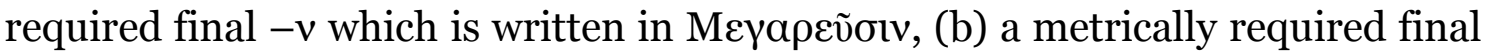
$-v$ that is not written in $\tilde{\varepsilon} v \pi \rho \circ \sigma \theta \varepsilon<v>$, (c) an optional $-v$ that is not written in the verse's word $\ddot{\alpha} \mu \mathrm{t}$. Also, it is metrically irrelevant whether one chooses the

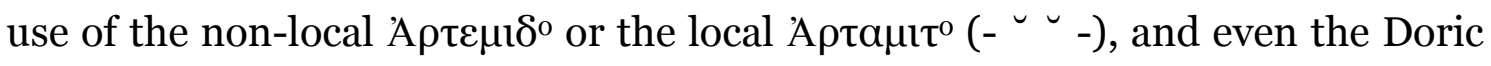
form of the article toi instead of oi.

The most striking equivalent metrical pairs are the forms with $\bar{\alpha}$ and $\eta$.

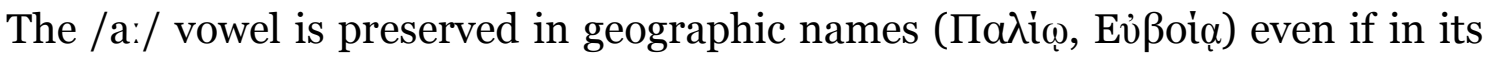
place of origin we expect $\eta(M<v>\kappa a \dot{\lambda} \alpha \varsigma)$. In poetic expressions $\bar{\alpha}$ is also maintained, such as in $\dot{\varepsilon} \lambda \varepsilon \dot{v} \theta \varepsilon \rho o v \tilde{\alpha} \mu \alpha \rho$, or in reference to Artemis ( $\dot{\alpha} \gamma v \tilde{\alpha} s$

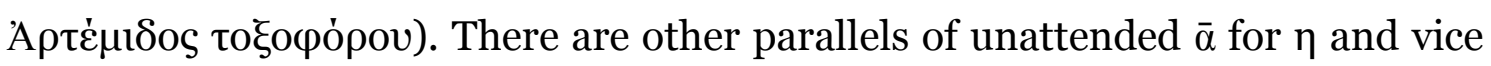
versa in pre-Hellenistic verse inscriptions. ${ }^{65}$ Thus, the presence of $\bar{\alpha}$ in Attic epigraphic poetry has been traditionally explained by the influence of lyric poetry, and that of $\eta$ by the influence of the epic Ionic in non-Attic-Ionic inscriptions. However, this sharp distinction does not always apply. The fact is that there are no unexpected examples of $\eta$ before the fourth $\mathrm{BC}$, when the $\eta$

9.707); however, this pronoun is less frequent at the end $(A P 1.119,15.40)$ or at the beginning (AP 10.108) of the verse.

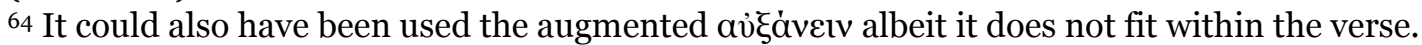

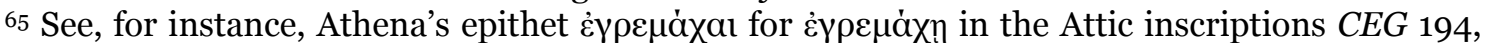
c.525-510 BC. For more examples and for a status quaestionis, see Mickey 1981:43-44 and more recently Guijarro Ruano 2016:229-245. 
spelling prevailed. Based on this evidence, we can raise two different hypotheses: (a) we should accept that the original version of the poem was composed right after the Persian Wars, and that thereafter $\dot{\alpha} \gamma o p \tilde{n}$, along with

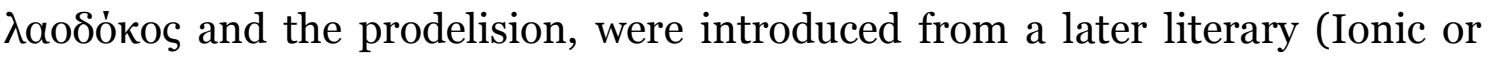
Ionic-based) version of the epigram. Otherwise, we should either admit that (b) there existed a later composition of the poem with an Ionic colouring, or (c) with a mixing of Doric and Ionic literary features, as we find in Hellenistic and Roman epigrams.

The main difficulty in analysing lexical pairs in contexts where metrics does not apply is that the entire text could have undergone a process of "Dorization" or "Ionization", that is, a process of linguistic transposition from its local original form into a more Doric or Ionic appearance. Our metrical text (at least regarding to the first distich) presents many similarities with other epigrams that make reference to the Persian Wars which have been preserved only in literary sources. From a linguistic point of view, there is no reason to deny a fifth century BC composition of the four first couplets of the epigram, since, as we have seen, apart from archaeological or historical issues, the extant version seem to present Doric or epichoric features.

A good parallel of linguistic levelling can be found in CEG 131 (Corinth, post $480 \mathrm{BC}$ ), a metrical inscription dedicated to the Corinthians fallen in Salamis, which was found near to the battlefield, in the contemporary Ambelaki. $C E G 131$ has also been preserved in a literary version that has standardized its language into Ionic or Koine dialect, but we only find Doric (or even epichoric) traits in it, such as лока or Ėvaíouعs. ${ }^{66}$ Likewise, an alleged fifth century BC epigram such as IG VII 53 could have been affected by a linguistic convergence towards a Doric coloration or to an Epic-Ionic varnish. Indeed, this is the last linguistic trend that later epigrams, literary or epigraphic, are going to develop.

Therefore, the recent linguistic features of the last couplet point to a later adding. In this sense, its linguistic traits can be connected to the setting-up of either a cenotaph or a tomb for the dead in the Megarian agora, although we cannot confirm an eventual transfer of human remains from the battlefield to

\footnotetext{
66 Page 1981:n. XI (Sim. 96 Bergk). In the version of Plutarch (De Hdt. mal. 870e) and Favorino

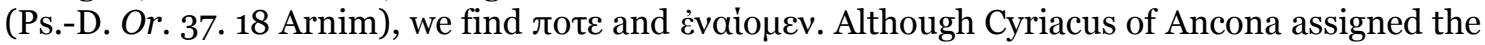
epigram to Thucydides, Favorino attributed authorsip to Simonides.
} 
the city. ${ }^{67}$ Once the epigram was lost, Helladios ordered to re-inscribe it. This hypothesis seems to offer a better explanation for the nature of both IG VII 53's text and monument.

\section{Conclusions}

Based on a linguistic analysis of $I G$ VII 53, we can conclude that there are no certain epichoric traits in the extant text of the epigram. If they did exist, they would have appeared in a context of metrical equivalence ( $\mathrm{F}^{-}, \mu \mathrm{h}$ - spellings,

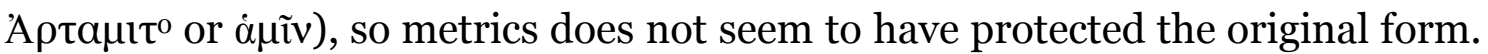

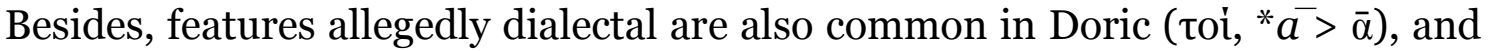
other traits such as the lack of $-v$ in $\tilde{\varepsilon} \mu \pi \rho \circ \theta \varepsilon \varepsilon$ can be explained as mistakes or simply as more recent additions if the original epigram was composed in the fifth century BC (as it happens in the case of the aphaeresis in ' $v$ or in

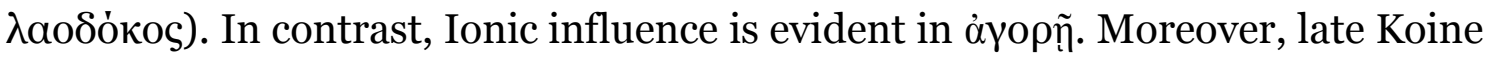

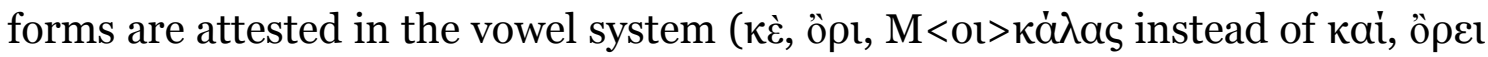

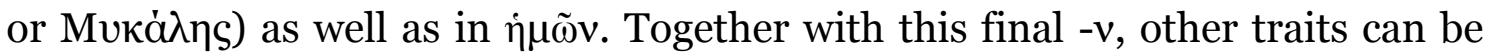
considered poetical tools useful to the composer, such as the lexical pairs ( $\tilde{\alpha} \mu \alpha \rho$

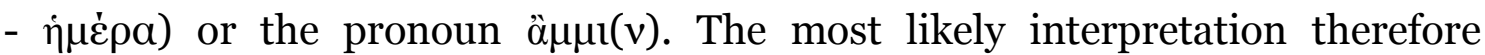
suggests that the original epigram was composed in the fifth century BC. In essence, the antiquity of the verses for the war-dead Megarians during the Persian conflict cannot be denied. However, regardless of the historic events, we cannot exclude the possibility of a later composition during the Hellenistic period with an intended archaic style.

To the contrary of Page's view on an entire fifth-century original epigram, ${ }^{68}$ there are four linguistic features supporting the idea of a final patched couplet which also endorse Petrovic's interpretation concerning the recent date of the last couplet:69 (a) the lesbian pronoun $\ddot{\alpha} \mu \mu$, metrically

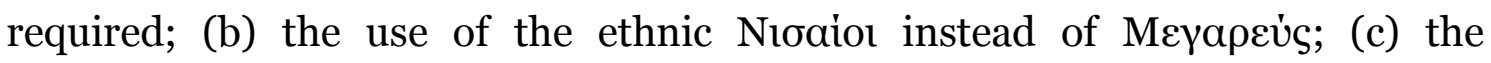

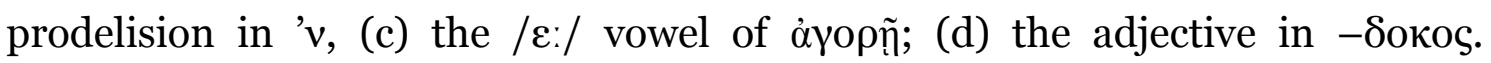
Excepting the first item, the last three features are gathered in $\lambda$ aodó $\kappa \omega<l>$ ' $v$

${ }^{67}$ According to Prandi 1990:61-65, there is no evidence of relocation of the dead in Athens, but that must have been the case for Corinthians, Megarians, and the Spartan king Leonidas. This is the idea behind $I G$ VII 53 .

68 Page 1981:215.

69 Petrovic 2007:194-208. 
àyopñ. Furthermore, Helladios' copy of the text must have originated from a literary version of the epigram on account of its attribution to Simonides, as it was generally the case in the epigrammatic anthologies. The final prose line also resembles a sentence from a comment glossing the edition of the verses.

To conclude, the entire text is better explained on the basis of two different phases that concern the composition of the epigram and the construction of the monument. In the first phase, an original epigram was created for a polyandrion erected in honour of fallen Megarians on the occasion of the Persian Wars in the fifth century BC. Keeping in mind other cases of confirmed linguistic standardization in similar inscriptional epigrams such as $C E G$ 131, it is likely that the epigram of IG VII 53 was composed in Doric. We cannot exclude, however, the influence of the epichoric dialect in the text over this period. Hence, recent linguistic traits, such as $\eta$ instead of $\alpha$ ( $\dot{\gamma} \gamma o \rho \tilde{)})$, may have been incorporated later into a local anthology of Persian warlike epigrams assigned to the poet of Ceos. In a second phase, a monument (tò үépas) was built as a cenotaph or grave for the dead. This monument was later identified in the imperial period by Pausanias and the Megarians as actual graves where Megarian soldiers received heroic cult, as Plutarch reminds us: $\mu \dot{\varepsilon}_{\chi} \rho \mathrm{\rho} \iota \dot{\varepsilon} \varphi ’ \hat{\eta} \mu \tilde{\omega} v$

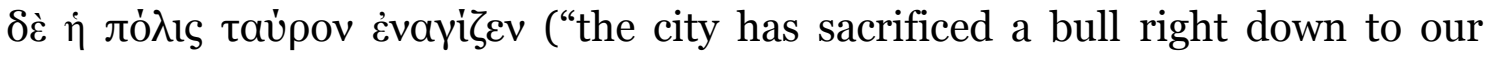
day"). The final distich thus confirms linguistically the likelihood of this twophase hypothesis.

Finally, it is worthy to establish a parallel between the history of $I G$ VII 53 and $A P$ VII 249, a literary epigram allegedly ascribed to Simonides. If there was an original inscribed version of $A P$ VII 249, it would have been lost, but from its literary transmission we know that $A P$ VII 249 was the well-known epigram dedicated to Leonidas and the Spartan soldiers fallen in the battle of Thermopylae. It would be as if the Lacedemonians one, two, three, or even hundred years later decided to inscribe in an outstanding place the famous epigram of their fallen in the Thermopylae, an epigram which was also transmitted under Simonides' name. Since metrics does not help to preserve local forms, it is a very difficult task in both cases to determine precisely both how was and how long took the flight of these epigraphic (rarae) aves to our days. 


\section{Bibliography}

Argentieri, L. "Meleager and Philip as Epigram Collectors". In P. Bing y J. Bruss (eds) Brill's Companion to Hellenistic Epigram. Leiden: Brill, 2007, 147-164.

Del Barrio Vega, M. L. El Dialecto de Eubea. Universidad Complutense de Madrid. Tesis doctoral inédita. Madrid, 1986.

Bechtel, F. Die griechische Dialekte 2. Die westgriechischen Dialekte. Berlin: Weidmann, 1923.

Bergk, T. Poetae Lyrici Graeci, vol. III. Leipzig: Teubner, 1882.

Boas, M. De epigrammata Simonideis. Pars prior: Commentatio critica de epigrammatum traditione. Groningae: J.B. Wolters, 1905.

Boeckh, A. Gesammelte kleine Schriften. Opuscula academica Berolinensia, vol. IV, Leipzig: Teubner, 1874.

Boedecker, D. "The New Simonides and heroization at Plataia". In Fisher \& van Wees (eds.) Archaic Greece: New Approaches and New Evidence. London: Duckworth, 1997.

Bravi, L. Gli Epigrammi di Simonide e le Vie della Tradizione. Roma: Edizioni dell'Ateneo, 2006.

$C E G=$ Hansen, P.A. Carmina epigraphica Graeca, 2 vols. Berlin: De Gruyter, 1983-1989.

Chaniotis, A. Historie und Historiker in den griechischen Inschriften. Stuttgart: Steiner, 1988.

"Ritual dynamics in the Eastern Mediterranean: Case studies in ancient Greece and Asia Minor". In Harris (ed.) Rethinking the Mediterranean. Oxford; New York: Oxford University Press, 2005, 141-156.

Chantraine, P. Grammaire Homérique. Tome 1, Phonétique et morphologie. Paris: Klincksieck, 1958.

$C I G=$ Boeckh, A. Corpus inscriptionum Graecarum, 4 vols. Berolino: Ex Officina academica: Vendit G. Reimeri libraria, 1828-1877.

Clairmont, Ch. Patrios Nomos. Public Burial in Athens During the Fifth and Fourth Fenturies BC; The Archaeological, Epigraphic-Literary and Historical Evidence. Oxford: BAR, 1983.

$D E ́ L G=$ Chantraine, P. Dictionnaire Étymologique de la Langue Grecque: Histoire des Mots. Paris: Klincksieck, 2009.

$D G E=$ Rodríguez Adrados, F. et al. Diccionario Griego Español. Madrid: CSIC, 2002-2009.

Diehl, E. Anthologia Lyrica Graeca. Leipzig: Teubner, 1949-1952.

Ekroth, G. The Sacrificial Rituals of Greek Hero-Cults in the Archaic to the Early Hellenistic Periods (Kernos Supplements 12). Liège: Centre international d'étude de la religion grecque antique, 2002.

Friedländer, P. "Geschichtswende im Gedicht. Interpretationen historischer Epigramme”, SIFC, vol. 15, 1938, 89-120. 
GHI = Tod, M.N. A Selection of Greek Historical Inscriptions. Oxford: Clarendon Press, 1933.

GVI = Peek, W. Griechische Versinschriften. Berlin: Österreichischen Akademie der Wissenschaften, 1955.

Guijarro Ruano, P. La Lengua de las Inscripciones Métricas del Peloponeso (Siglos VII-IV a.C.). Universidad Complutense de Madrid. Tesis doctoral inédita. Madrid, 2016.

Hiller von Gaertringen, F. Historische griechische Epigramme. Bonn: Marcus \& Weber, 1926.

Jacoby, F. "Some Athenian epigrams from the Persian Wars". Hesperia, vol. 14, 1945, 157-211.

Martin, E. Recherches Sur l'Agora Grecque: Études d'Histoire et d'Architecture Urbaines. Paris: E. de Boccard, 1951.

Kaibel, G. "Quaestiones Simonideae". $R H$, vol. 28, 1873, 436-460.

LSJ = Liddell, H.; Scott, R.; Johnes, H. and McKenzie, R. A Greek-English Lexicon, $9^{\text {th }}$ ed. Oxford; New York: Clarendon Press, 1996.

Mickey, K. "Dialect consciousness and literary language. An example from ancient Greek". TPhS, vol. 79, 1981, 35-66.

Molyneux, J.H. Simonides. A Historical Study. Wauconda: Bolchazy-Carducci Publishers, 1992.

Page, D. Epigrammata Graeca. Oxford: E Typographeo Clarendoniano, 1975. Further Greek Epigrams. Oxford: Cambridge University Press, 1981.

Petrovic, A. Kommentar zu den simonideischen Versinschriften. Leiden; Boston: Brill, 2007.

Pfohl, G. Griechische Inschriften als Zeugnisse des privaten und öffentlichen Lebens. München: Heimeran, 1966.

Podlecki, A.J. "Epigraphica Simonidea”. Epigraphica, vol. 35, 1973, 24-39.

Prandi, L. "I Caduti delle guerre persiane: Morti per la città o morti per la Grecia?”. In M. Sordi (ed.) Dulce et decorum est pro patria mori: La Morte in Combattimento Nell'Antichità. Contrinbuti dell'Istituto di Storia Antica. Milano: Vita e penseiero, 1990, 47-68.

Schörner, H. Sepulturae Graecae intra urbem. Untersuchungen zum Phänomen der intraurbanen Bestattung bei den Griechen. Möhnesee: Bibliopolis, 2007.

Sider, D. (2007) "Sylloge Simonidea". In Bing \& Bruss (eds) Brill's Companion to Hellenistic Epigram. Leiden: Brill, 113-130.

Von Kamptz, H. Homerische Personennamen. Göttingen: Vandenhoeck \& Ruprecht, 1982.

Vries, G. J. Griekse epigrammen. Zwolle: W.E.J. Tjeenk-Willink, 1967.

Wade-Gery, H.-T. "Classical epigrams and epitaphs. A study of the Kimonian Age". JHS, vol. 53, 1933, 71-104.

Wilhem, A. "Simonideische Gedichte", JÖAI, 1899, 236-244. 